\title{
ALIEN FLORA OF THE CITY OF BANJA LUKA (BOSNIA AND HERZEGOVINA)
}

\author{
Biljana Lubarda ${ }^{1} \&$ LjILjana Topalić-Trivunović ${ }^{2}$ \\ ${ }^{1}$ University of Banja Luka, Faculty of Natural Sciences and Mathematics, Department of biology, \\ Mladena Stojanovića 2,78000 Banja Luka. Bosnia and Herzegovina \\ (biljana.lubarda@pmf.unibl.org) \\ ${ }^{2}$ University of Banja Luka, Faculty of Technology. Bulevar vojvode Stepe Stepanovića 73, 78000 \\ Banja Luka. Bosnia and Herzegovina \\ (ljiljana.topalic-trivunovic@tf.unibl.org)
}

Lubarda, B. \& Topalić-Trivunović, Lj.: Alien flora of the city of Banja Luka (Bosnia and Herzegovina). Nat. Croat., Vol. 29, No. 2, 217-226, 2020, Zagreb.

In the urban area of Banja Luka, 77 species of alien plants have been found, most of them neophytes $(64.94 \%)$ while a smaller percentage are archeophytes (35.06\%). Most of the plants originate from America (34), and Asiatic species rank second (17). Most of the alien plants belong to the Compositae family, in terms of life form are therophytes, and intention has been involved in their arrival in this area.The anthropogenic change indicator values have been shown to have a significant anthropogenic impact on the overall flora.

Key words: Alien plants, Banja Luka, urban flora

Lubarda, B. \& Topalić-Trivunović, Lj.: Alohtona flora grada Banja Luke (Bosna i Hercegovina). Nat. Croat., Vol. 29, No. 2, 217-226, 2020, Zagreb.

Na urbanom području grada Banja Luke pronađeno je 77 vrsta alohtonih biljaka, od kojih su većina neofiti $(64,94 \%)$, a manji postotak su arheofiti $(35,06 \%)$. Najveći broj biljaka potječe iz Amerike (33), a na drugom mjestu su azijske vrste (21). Većina alohtonih biljaka pripadaju porodici Compositae, životnoj formi terofita i namjerno su unesene na ovo područje. Vrijednosti indikatora antropogenih promjena pokazale su znatni antropogeni uticaj na ukupnu floru.

Ključne riječi: alohtone biljke, Banja Luka, urbana flora

\section{INTRODUCTION}

Urban habitats are very heterogeneous, which makes them suitable for the establishment of numerous alien species (SARAJLIć \& NeJC, 2017). Because of the strong anthropogenic influence on the urban flora, the following can be noted: a) disturbances change the composition of urban flora compared to the original state, $b$ ) the composition of urban flora differs from flora in non-urban habitats and d) there is a strong floristic similarity among different urban areas (WiтоsŁAwsкi \& BoмANovsKa, 2009).

Alien plants, also known as exotic, adventive, introduced, allochthonous, non-indigenous and non-native are plant species whose presence in a given area is the result of deliberate or unintentional human activity or which have arrived in a given area without human assistance (PYŠEK, 1995; RichARdson et al., 2000; PYšEK et al., 2004). Alien plants include a large group of plants. For example, they include most types of crop plants used for human consumption. Some alien plants are invasive and represent a 
threat to biodiversity as well as to humans. Alien plants are species, subspecies or lower plant taxa introduced and growing outside of their natural area of distribution (this includes any part of gametes, seeds or propagules of such a taxon that might survive and subsequently reproduce) (Miтić et al., 2008).

Floristic urban habitat research in the area of Bosnia and Herzegovina is modest. Comprehensive analyses exist only for Mostar (MAsLo, 2014) and Sarajevo (Tomović-HADŽIAvdić \& ŠolJAN 2006). The situation with the flora and vegetation research in Banja Luka is similar. The most significant research on the urban flora and vegetation of Banja Luka is that of the doctoral thesis Topalić-Trivunović (2005). When it comes to exploring alien plant species in urban areas, the situation is very similar. Alien flora surveys were conducted on the territory of Mostar (MASLO, 2015) and Sarajevo (SARAJLIĆ \& JoGAN, 2017).

An analysis of alien flora in the area of the city of Banja Luka is given by TopALIĆ-TRIvunović \& Pavlović-Muratspahić (2008), this paper including only those taxa that were introduced into these areas in the period after the year 1500 (approximately from the year of the discovery of America). According to the results of these researches in the area of Banja Luka, the presence of 61 species of adventitious plants was ascertained.

This paper presents a list of previously recorded alien species that were introduced into this area intentionally or unintentionally by human activity in the period from the beginning of Neolithic agriculture to the end of the Middle Ages (archaeophytes) as well as those introduced later (neophytes). We report on a brief analysis of alien plant species, which includes an analysis of the participation of archaeophytes and neophytes in the studied flora, and also provides anthropophysical indices.

\section{MATERIAL AND METHODS}

Banja Luka is located on the banks of the Vrbas river in an extensive basin, at the crossing between the Pannonian Plain and the Dinaric Mountains. The basin of Banja Luka, with an altitude from 130 to $170 \mathrm{~m}$ above sea level, extends from southwest to north and northeast. The Banja Luka area is located in the area where the mountains of central Bosnia cross the hilly terrain into the plains of Lijevče Polje and Posavina. The narrowest part of the city is in the south and at the exit of the Vrbas from the gorge into the plain. In the urban area, the Suturlija and the Crkvena from the left side and the Vrbanja from the right flow into the Vrbas (Fig. 1).

Field surveys of the flora in the area of the city Banja Luka were conducted during four growing seasons. The survey covered the urban area of the city as well as settlements in the outskirts. Taxa that are present in culture exclusively are not covered by these studies. Determination of plant taxa was performed after the standard literature (Javorka \& Csapody, 1979; Tutin et al., 1964-1980, 1993) and the nomenclature was adjusted according to Euro + Med Plant Base (http://ww2.bgbm.org/EuroPlusMed/). The plant species are arranged alphabetically and next to each species in the list are the following attributes: family, life form, introduction period, origin, and invasive status (Appendix 1). The life-form categories follow Raunkiaer (1934), Stevanović (1992) and marked with the standard abbreviations in the list of urban flora: Ch (Chamaephyta), G (Geophyta), H (Hemicriptophyta), S (Scandetophyta), P (Phanerophyta) and $\mathrm{T}$ (Therophyta). All taxa are classified into three categories depending on the degree of their naturalization: casual taxa (CAS), naturalized non-invasive taxa (NAT) 


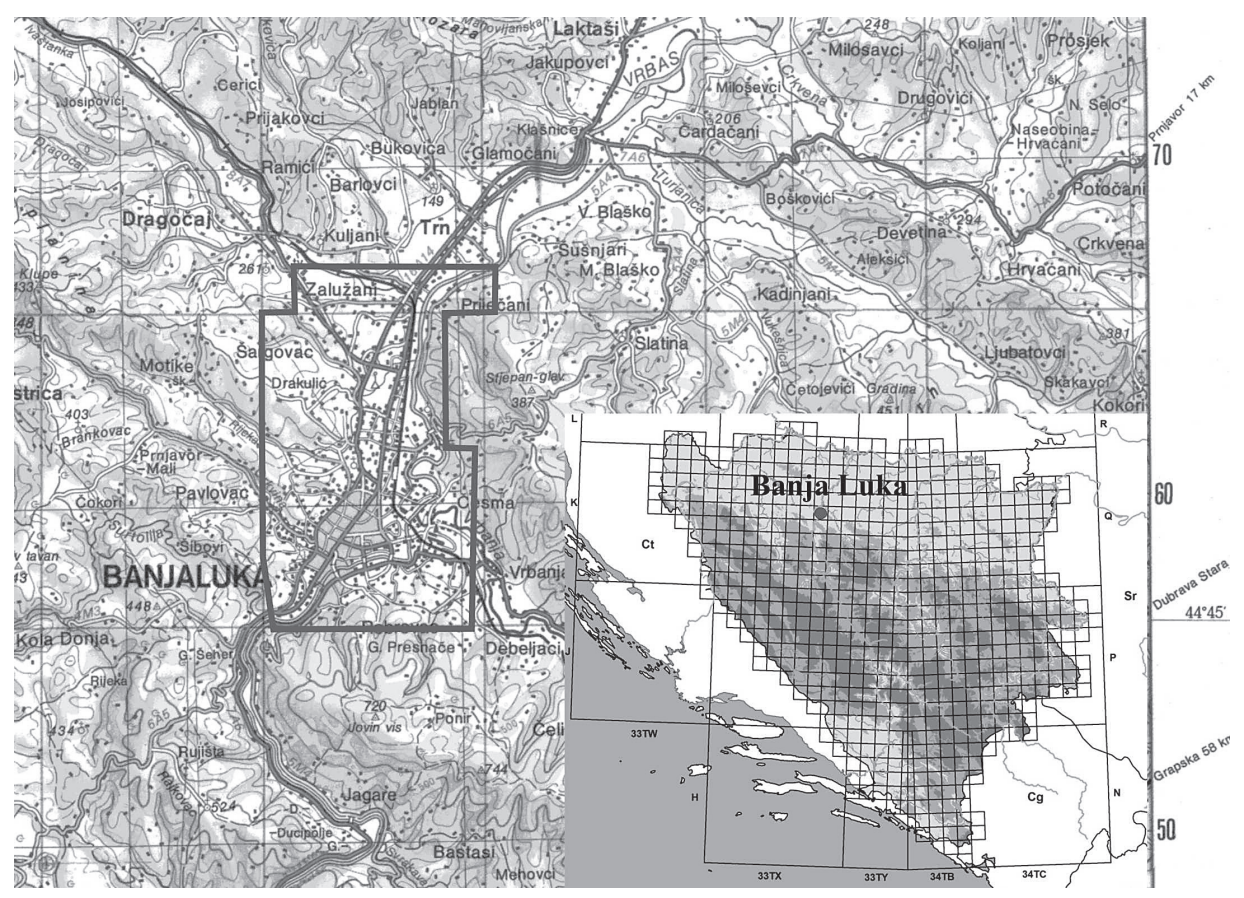

Fig. 1. Location and boundaries of the researched area (detail from the topographic map Banja Luka $1: 200000)$

and naturalized invasive taxa (INV). Estimated mode of introduction into the region (deliberate, by planting - DEL, accidental - ACC or in both modes - D-A).

Landolt et al. (2010), Medvecká et al. (2012) and Pүš́k et al. (2002, 2004) have largely been acceped for determination of origin, i.e. type and time of introduction . The terminology and definitions recommended by RicHARDson et al. (2000), PYšEK et al. (2004), Boršić et al. (2008) and Mitić et al. (2008) were used to establish the status of alien plants. The groups used are: Sp - spontaneophytes (native plants), Ar (ARC) - archaeophytes, established alien species introduced intentionally or unintentionally before 1500, Kn (NEO) - kenophytes (neophytes), alien species introduced intentionally or unintentionally after 1500 and Df (CAS) - diaphytes (casual alien plants), alien species not permanently established.

We calculated three groups of indicators of changes in the flora related to anthropogenic impact according to JАскошіAK $(1990,2006)$ as follows:

1. Indicators of anthropization

1.1. $\mathrm{IAn}_{\mathrm{t}}-$ indicator of total anthropization, $\mathrm{IAn}_{\mathrm{t}}=(\mathrm{An} /(\mathrm{Sp}+\mathrm{An}))^{*} 100$;

1.2. $\mathrm{IAn}_{\mathrm{p}}-$ indicator of permanent anthropization, $\mathrm{IAn} n_{\mathrm{p}}=\left(\mathrm{Mt} /(\mathrm{Sp}+\mathrm{Mt})^{*} 100\right.$;

2. Indicators of archaeophytization

2.1. $\mathrm{IAr}_{\mathrm{t}}-$ indicator of total archaeophytization, $\mathrm{IAr}_{\mathrm{t}}=\left(\mathrm{Ar} /(\mathrm{Sp}+\mathrm{An})^{*} 100\right.$;

2.2. $\mathrm{IAr}_{\mathrm{p}}-$ indicator of permanent archaeophytization, $\operatorname{IAr}_{\mathrm{p}}=\left(\mathrm{Ar} /(\mathrm{Sp}+\mathrm{Mt})^{*} 100\right.$; 
3. Indicators of kenophytization

3.1. $I K n_{t}-$ indicator of total kenophytization, $\mathrm{IKn}_{\mathrm{t}}=\left(\mathrm{Kn} /(\mathrm{Sp}+\mathrm{An})^{*} 100\right.$;

3.2. $\mathrm{IK} \mathrm{n}_{\mathrm{p}}$ - indicator of permanent kenophytization, $\mathrm{IK} \mathrm{n}_{\mathrm{p}}=\left(\mathrm{Kn} /(\mathrm{Sp}+\mathrm{Mt})^{*} 100\right.$;

4. IM - indicator of modernization, $\mathrm{IM}=(\mathrm{Kn} / \mathrm{Mt})^{*} 100$;

5 . IF - indicator of fluctuation changes, $\mathrm{IF}=\left(\mathrm{Df} /(\mathrm{Sp}+\mathrm{An})^{*} 100\right.$;

-where An is the number of anthropophytes (alien species i.e. An=Ar + Kn + Df) and Mt is the number of metaphytes (permanently established alien species, i. e. $\mathrm{Mt}=\mathrm{Ar}+\mathrm{Kn}$ ).

\section{RESULTS}

In the area of Banja Luka, 77 alien plants belonging to 65 genera and 30 families were recorded (Appendix 1). The families with the highest number of taxa were: Compositae (24.68\%), Poaceae (9.09\%) Fabaceae and Brassicaceae (6.49\%) (Tab. 1).

Tab. 1. The most abundant families in the alien flora of the city of Banja Luka

\begin{tabular}{|l|c|c|}
\hline Family & No. of taxa & \% of total alien flora \\
\hline Compositae & 19 & 24.68 \\
\hline Poaceae & 7 & 9.09 \\
\hline Brassicaceae & 5 & 6.49 \\
\hline Fabaceae & 5 & 6.49 \\
\hline Polygonaceae & 4 & 5.19 \\
\hline Solanaceae & 3 & 3.89 \\
\hline Sapindaceae & 3 & 3.89 \\
\hline Plantaginaceae & 3 & 3.89 \\
\hline
\end{tabular}

The presence of 50 neophytes (64.94\%) and 27 archaeophytes (35.06\%) was recorded in the alien flora of Banja Luka (see Appendix 1). Most of alien plants found in the territory of Banja Luka come from the Americas - 34 taxa (44.15\%). Among them, more than two-thirds belong to North American species (24 species). Alien species native to Asia were represented by 17 taxa $(22.08 \%)$. Alien plants originating from the Mediterranean also had a high share and were represented by an equal number of species (16). Other plant groups are only slightly represented.

The analysis of life forms revealed the dominance of therophytes with 40 species (52.0\%), of which 4 taxa belonged to the transitional life form of therophytes and hemicryptophytes. They were followed by hemicryptophytes with 12 species $(15.6 \%)$. Phanerophytes were represented by 11 species $(14.3 \%)$, of which two were lianas or scandentophytes (Tab. 3).

The analysis of the mode of introduction into the region showed that the largest number of species in the alien flora of Banja Luka were planted intentionally (DEL; 41 taxa or $53.25 \%$ ). This was followed by plants that arrived accidentally (ACC; 30 taxa or $38,96 \%)$. The fewest taxa were introduced both ways, deliberately and accidentally (6 taxa; $7.79 \%$ ). The analyses of the degree of naturalization showed that a large number of plants in the alien flora of Banja Luka belonged to the group of casual plants or 
Tab. 2. Analysis of the geographical origin of the alien flora of the city of Banja Luka

\begin{tabular}{|l|l|c|c|}
\hline Geographic region & \multicolumn{1}{|c|}{ Sub-region } & No. of taxa & \% of total alien flora \\
\hline AFRICA & & 1 & 1.30 \\
\hline AMERICA & & 34 & 44.15 \\
\hline & Central \& North America & 3 & \\
\hline & Central America & 2 & \\
\hline & North America & 24 & \\
\hline & North \& South America & 1 & \\
\hline & South America & 4 & \\
\hline ASIA & & & \\
\hline & & 17 & \\
\hline & Asia & 5 & \\
\hline & Central Asia & 1 & \\
\hline & East Asia & 5 & \\
\hline & East \& Central Asia & 1 & \\
\hline & South \& East Asia & 1 & \\
\hline & South-West Asia & 3 & \\
\hline EUROPE & West Asia & 1 & \\
\hline EUROPE, ASIA & & 2 & 2.60 \\
\hline MEDITERRANEAN & & 2 & 2.60 \\
\hline UNKNOWN & & 16 & 20.78 \\
\hline ORIGIN & & 5 & 6.49 \\
\hline TOTAL & & 77 & 100.00 \\
\hline
\end{tabular}

Tab. 3. Life form spectrum of the alien flora of the city of Banja Luka

\begin{tabular}{|c|c|c|}
\hline Life form & No. of taxa & \% of total alien flora \\
\hline Ch & 2 & 2.6 \\
\hline G & 7 & 9.1 \\
\hline H & 12 & 15.6 \\
\hline P & 9 & 11.7 \\
\hline S & 2 & 2.6 \\
\hline ST & 5 & 6.5 \\
\hline T & 36 & 46.8 \\
\hline T/H & 4 & 5.2 \\
\hline TOTAL & 77 & 100 \\
\hline
\end{tabular}

diaphytes (31 taxa; 40.26\%). These species have most often escaped from cultivation or been established accidentally and have been unable to form stable populations in the new conditions. Naturalized plants, which form stable populations, are represented by 47 taxa. According to the definition of RicHARDSON et al. (2000), the presence of 25 invasive species was recorded in the urban flora of Banja Luka. Species such as: Reynoutria japonica, Ambrosia artemisiifolia, Ailanthus altissima and Erigeron annuus had the highest frequency (Appendix 1). 
According to previous research, in the wider area of Banja Luka, the total flora has 549 taxa (ToPALić-TRIvunović, 2005). The indicators of anthropophytization $\left(\operatorname{IAn}_{t}=14.03 \%\right.$; $\left.\operatorname{IAn}_{p}=9.06 \%\right)$ showed that the total flora of Banja Luka has been subject to a considerable anthropogenic influence. Indicators of anthropogenic changes indicated that the city flora of Banja Luka was more influenced by neophytes than by archaeophytes (Tab. 4). The total and permanent index values were very similar, indicating that the alien flora is well established. This was confirmed by low value of indicators of fluctuating changes $(5.46 \%)$. The relatively high indicator of modernization $(64.93 \%)$ showed the strong anthropogenic influence on the flora of Banja Luka.
Tab. 4. Indicators of anthropogenic changes in the city of Banja Luka

\begin{tabular}{|c|c|}
\hline Indicator & $\%$ \\
\hline $\mathrm{IAn}_{t}$ & 14.03 \\
\hline $\mathrm{IAn}_{\mathrm{p}}$ & 9.06 \\
\hline $\mathrm{IAr}_{t}$ & 4.92 \\
\hline $\mathrm{IAr}_{p}$ & 5.20 \\
\hline $\mathrm{IKn}_{t}$ & 9.10 \\
\hline $\mathrm{IKn}$ & 9.63 \\
\hline $\mathrm{IM}$ & 64.93 \\
\hline $\mathrm{IF}$ & 5.46 \\
\hline
\end{tabular}

\section{DISCUSSION}

Cities typically contain a large percentage of alien plants (WITTIG, 2004), primarily because of the developed infrastructure, enabling their dispersal, and the diversity of habitats exposed to the penetration of these species. During this research, we noted that the families with the highest number of taxa are Compositae and Poaceae. Similar results were obtained by research on the urban flora of Sarajevo (SARAJLIĆ \& NEJC, 2017), Mostar (Maslo, 2015), Sisak (Pruša et al., 2013), and Zagreb (Hudina et al., 2012) probably due to the high rate of reproduction and specialized structures of the fruits that allow for easier dispersal (PүšEK, 1997).

Most of the alien plants found in Banja Luka area from the Americas. Similar results were obtained for the alien plants of Podgorica (SteŠEvić et al., 2014), Mostar (MAsLo, 2015) and Sarajevo (SARAjLić \& NejC, 2017). It is interesting to note that the largest numbers of plants of American and Asian origin in cities belong to the neophyte group, while archaeophytes originate primarily from Europe and the Middle East and the Mediterranean (PYšEK et al., 2002).

The alien flora of Banja Luka has a terrophytic character. The high share of therophytes is the result of the instability of most urban habitats, where intermittent or permanent anthropogenic interventions disturb the development of perennial plants. In addition, the openness of ruderal habitats with favorable light and thermal conditions mostly favors annual plants. Comparing the ecological analysis of the foreign flora of Banja Luka with the foreign flora of other cities, certain differences are observed. Specifically, an analysis of life forms in the urban flora of Mostar resulted in a higher proportion of phanerophytes than in Banja Luka. In these cities, a significant number of ornamental alien species escaped from cultivation.

During this research, a greater percentage of neophytes than of archaeophytes was recorded in the urban flora of Banja Luka. According to DEL TREDICI (2010), the ratio of neophytes to archaeophytes rises in direct relation to the intensity of human disturbance. Archaeophytes are usually associated with rural environments where the level of anthropogenic activity is medium high. Neophytes are more common in strongly disturbed anthropogenic habitats where the vegetation cover is low and in the areas where traffic and industrial infrastructure dominate. 
Anthropophytization indicators $\left(\operatorname{IAn}_{t}=14.03 \%\right.$; $\left.\operatorname{IAn}_{p}=9.06 \%\right)$ showed significant anthropogenic impact on the overall flora of Banja Luka. Very similar values were obtained by analyzing the alien flora of the city of Sarajevo $\left(\operatorname{IAn}_{t}=12.09 \%\right.$; $\left.\operatorname{IAn}_{p}=8.17 \%\right)$ Sarajlić \& Nejc, (2017) or Mostar given by Maslo $(2014,2015)$. Higher values of the anthropophytization index in Rzeszów Foothills, south-eastern Poland, $\left(\operatorname{IAn}_{t}=21.3 \%\right)$ are the result of a high percentage of alien flora in urban areas of south-eastern Poland compared to the total flora. In the countries of northern and central Europe, many species of plants of Mediterranean origin are marked as archaeophytes, while in our country they are marked as native.

\section{CONCLUSION}

In the area of Banja Luka, the alien flora consists of 77 taxa classified into 65 genera and 30 families. Plant families with the most representatives are Compositae, Poaceae and Brassicaceae. Most of the alien species are neophytes. The analysis of life forms determined the dominance of therophytes. The majority of species in the alien flora of Banja Luka were introduced deliberately (53.25\%). According to the geographical origin, the largest numbers of alien plants recorded originate from the Americas (44.15) and Asia (22.08). Among alien species recorded in Banja Luka, 25 are invasive. The high value of the anthropophytization index shows that there is considerable human influence on the flora of the city of Banja Luka. The largest number of alien species occurs in habitats under permanent anthropogenic impact, along the roads, landfills and banks of the Vrbas River.

Received January 24, 2020

\section{REFERENCES}

Boršić, I., Milović, M., Dujmović, I., Bogdanović, S., Cigić, P., RešEtnik, I., Nikolić, T. \& Mitić, B., $2008:$ Preliminary check-list of invasive alien plant species (IAS) in Croatia. Natura Croatica 17, 55-71.

Del Tredici, P., 2010: Spontaneous urban vegetation - reflections of change in a globalized world. Nature and Culture 5, 299-315.

Euro+Med, 2006-: Euro+MedPlantBase - the information resource for Euro-Mediterranean plant diversity. Published on the Internet http://ww2.bgbm.org/EuroPlusMed/

Hudina, T., Salkić, B., Rimac, A., Bogdanović, S., \& Nikolić, T., 2012: Contribution to the urban flora of Zagreb (Croatia). Natura Croatica 21, 357-372.

Javorka, S. \& Csapody, V., 1975: Iconographie der Florae des Südöstlichen Mitteleuropa. Akademija Kiado, Budapest.

JаскошіAк, B.,1990: Antropogeniczne przemiany flory roślin naczyniowych Poznania. Wydawnictwo Naukowe Uniwersytetu Adama Mickiewicza w Poznaniu, ser. Biologia 42, 1-208.

Jаскошіак, В. 2006: Methodological proposals for studies on the structure and dynamics of urban flora. Polish Botanical Studies 22, 251-260.

Jaźwa, M. \& Stadnicka-Futoma, A., 2015: The alien flora of the Rzeszów Foothills. Biodiversity 38, 25-36.

Landolt, E., Bäumler, B., Erhardt, A., Hegg, O., Klötzli, F., Lämmler, W., Nobis, M., Rudmann-Maurer, K., Schweingruber, F. H., Theurillat, J-P., Urmi, E., Vust, M. \& Wohlgemuth, Th., 2010: Flora indicativa. Ökologische Zeigwerte und biologische Kennzeichenzur Flora der Schweiz und der Alpen. Editions des Conservatoire et Jardin botaniques de la Ville de Genève and Haupt Verlag, Bern-Stuttgart-Wien.

Maslo, S., 2014: The urban flora of the city of Mostar (Bosnia and Herzegovina). Natura Croatica 23, 101-145.

MasLo, S., 2015: Alien flora of the city of Mostar (Bosnia and Herzegovina). Herbologia, 15, 1-16. 
Medvecká J., Kliment J., Májeková J., Halada L., Zaliberová M., Gojdičová E., Feráková V. \&Jarolímek I., 2012: Inventory of the alien flora of Slovakia. Preslia 84, 257-309.

Mitić, B., Boršić, I., Dujmović, I., Bogdanović, S., Milović, M., Cigić, P., Rešetnik, I. \& Nikolić, T., 2008: Alien flora of Croatia: proposals for standards in terminology, criteria and related database. Natura Croatica 17, 73-90.

PrušA, M., MaJić, B. \& Nikolić, T., 2013: Invazivna flora gradaSiska (Hrvatska). GlasnikHrvatskogbotaničkogdruštva, 1, 4-17.

PyšeK, P., 1995: On the terminology used in plant invasion studies. In: PүšEK, P., Prach, K., RejmaneK, M., WADE, M. (eds.) Plant invasions: general aspects and special problems SPB,Academic Publishing, Amsterdam, 71-81.

PYšEK, P., 1997: Compositae as invaders- better than the others? Preslia, 62, 9-22.

PүšEK, P., 1998: Alien and native species in Central European urban floras: a quantitative comparison. Journal of Biogeography 25, 155-163.

Pyšek, P., Richardson, D.M., Rejmanek, M., Webster, G.L., Williamson, M. \& Kirschner, J., 2004: Alien plants in checklists and floras: towards better communication between taxonomists and ecologists. Taxon 53, 131-143.

PYŠEK, P., SÁLDo, J. \& MANDÁK, B., 2002: Catalogue of alien plants of the Czech Republic. Preslia, 74, 97-186.

Raunkiaer, C., 1934: The life forms of plants and statical plant geography. Clarendon Press, Oxford.

Richardson, D. M., Pyšek, P., Rejmanek, M., Barbour, M. G., Panetta, F. D. \& West, C. J., 2000: Naturalization and invasion of alien plants: concepts and definitions. Diversity \& Distributions 6, 93-107.

Sarajlić, N. \& Jogan, N. 2017: Alien flora of the city of Sarajevo (Bosnia and Herzegovina). Biologica Nyssana 8, 129-136.

StešEvić, D., CAković, D. \& Jovanović, S., 2014: The Urban Flora of Podgorica (Montenegro, SE Europe): Annotated Checklist, Distribution Atlas, Habitats and Life-Forms, Taxonomic, Phytogeographical And Ecological Analysis. EcologiaMontenegrina, Suppl. 1, 1-171.

Stevanović, V. 1992: Klasifikacija životnih formi flore Srbije. In SARić, M. (ed.): Flora Srbije I. (Drugoizdanje), SANU. Beograd, 37-49.

Tomović-HadžIAvdić, V. \& ŠoljAn, D., 2006: Urbana flora Sarajeva. Glasnik Zemaljskog muzeja (prirodne nauke), Nova sveska 32, 121-135.

Topalić-Trivunović, Lj., 2005: Ruderalna flora i vegetacije područja Banja Luke. Doktorska disertacija. Prirodno-matematičkifakultetUniverziteta u Banjoj Luci.

Topalić-Trivunović, Lj. \& Pavlović-Muratspahić, D., 2008: Adventive flora of the Banja Luka Region. Acta herbologica 17, 109-117.

Tutin, T. G., Heywood, V. H., Burges, N. A., Valentine, D. H., Walters, S. M. \& Webb D. A. (eds.), 19641980: Flora Europaea 1-5. Cambridge University Press, Cambridge.

Tutin, T. G., Burges, N. A., Chater, A. O., Edmondson, J. R., Heywood, V. H., Moore, D. M., Valentine, D. H., Walters, S. M. \& Webb, D. A. (EDs.), 1993: Flora Europaea 1, ed. 2., Cambridge University Press, Cambridge.

WitosŁawski, P. \& Bomanowska, A., 2009: Southern European species in the flora of towns in the central Poland. Botanica Serbica 33, 115-129.

WitTIG, R., 2004: The origin and development of the urban flora of Central Europe. Urban Ecosystems 7, 323-333. 


\section{Appendix 1.}

Alien flora of the city of Banja Luka (LF-life form, PI-period of introduction, NAT- naturalization, MI-mode of introduction, O-origin)

\begin{tabular}{|c|c|c|c|c|c|c|c|}
\hline & Taxon & Family & LF & PI & NAT & MI & $\mathrm{O}$ \\
\hline 1. & Acer negundo L. & Sapindaceae & $\mathrm{P}$ & $\mathrm{NEO}$ & INV & DEL & $\operatorname{Am}(C \& N)$ \\
\hline 2. & Acer saccharinum $\mathrm{L}$. & Sapindaceae & $\mathrm{P}$ & NEO & CAS & DEL & $\operatorname{Am}(\mathrm{N})$ \\
\hline 3. & Aesculus hippocastanum L. & Sapindaceae & $\mathrm{P}$ & NEO & CAS & DEL & $\mathrm{M}$ \\
\hline 4. & Ailanthus altissima (Mill.) Swingle & Simaroubaceae & $\mathrm{P}$ & NEO & INV & DEL & As (E) \\
\hline 5. & Alcea biennisWinterl & Malvaceae & $\mathrm{H}$ & NEO & NAT & DEL & $\mathrm{M}$ \\
\hline 6. & Alcea rosea $\mathrm{L}$. & Malvaceae & $\mathrm{H}$ & ARC & NAT & DEL & unknown \\
\hline 7. & Amaranthus hybridus L. & Amaranthaceae & $\mathrm{T}$ & NEO & NAT & $\mathrm{ACC}$ & $\operatorname{Am}(\mathrm{N})$ \\
\hline 8. & Amaranthus retroflexus L. & Amaranthaceae & $\mathrm{T}$ & NEO & INV & $\mathrm{ACC}$ & $\operatorname{Am}(\mathrm{N})$ \\
\hline 9. & Ambrosia artemisiifolia $\mathrm{L}$. & Compositae & $\mathrm{T}$ & NEO & INV & ACC & $\operatorname{Am}(\mathrm{N})$ \\
\hline 10. & Amorpha fruticosa L. & Fabaceae & $\mathrm{P}$ & $\mathrm{NEO}$ & INV & ACC & $\operatorname{Am}(\mathrm{N})$ \\
\hline 11. & Anagallis arvensis L. & Primulaceae & $\mathrm{T}$ & ARC & NAT & $\mathrm{ACC}$ & $\mathrm{M}$ \\
\hline 12. & Anethum graveolens L. & Apiaceae & $\mathrm{T}$ & ARC & NAT & DEL & $\mathrm{M}$ \\
\hline 13. & Antirrhinum majus L. & Plantaginaceae & $\mathrm{T}$ & $\mathrm{ARC}$ & NAT & D-A & $\mathrm{M}$ \\
\hline 14. & Antirrhinum latifolium Mill. & Plantaginaceae & $\mathrm{T}$ & ARC & NAT & D-A & $\mathrm{M}$ \\
\hline 15. & $\begin{array}{l}\text { Armoracia rusticana P. Gaertn. , B. } \\
\text { Mey. \&Scherb. }\end{array}$ & Brassicaceae & G & ARC & CAS & D-A & $\mathrm{E}$ \\
\hline 16. & Artemisia annua L. & Compositae & $\mathrm{T}$ & NEO & INV & $\mathrm{ACC}$ & As (E) \\
\hline 17. & Avena sativa $\mathrm{L}$. & Poaceae & $\mathrm{T}$ & ARC & CAS & DEL & unknown \\
\hline 18. & Bassia scoparia (L.) A. J. Scott & Chenopodiaceae & $\mathrm{T}$ & NEO & CAS & $\mathrm{ACC}$ & E AS \\
\hline 19. & Beta vulgaris L. & Chenopodiaceae & $\mathrm{T} / \mathrm{H}$ & ARC & CAS & DEL & unknown \\
\hline 20. & Brassica nigra (L.) W. D. J. Koch & Brassicaceae & $\mathrm{H}$ & ARC & CAS & DEL & E \\
\hline 21. & Brassica rapa (L.) L. & Brassicaceae & $\mathrm{T} / \mathrm{H}$ & ARC & CAS & DEL & $\mathrm{M}$ \\
\hline 22. & Bromus arvensis L. & Poaceae & $\mathrm{T}$ & ARC & NAT & $\mathrm{ACC}$ & $\mathrm{M}$ \\
\hline 23. & Calendula officinalis L. & Compositae & $\mathrm{T}$ & ARC & CAS & DEL & $\mathrm{M}$ \\
\hline 24. & Callistephus chinensis (L.) Nees & Compositae & $\mathrm{T}$ & NEO & CAS & DEL & As (E\&C) \\
\hline 25. & Canabis sativa L. & Cannabaceae & $\mathrm{T}$ & ARC & NAT & DEL & As (C) \\
\hline 26. & Commelina communis L. & Commelinaceae & $\mathrm{H}$ & NEO & NAT & DEL & As (E) \\
\hline 27. & Cosmos bipinnatus Cav. & Compositae & $\mathrm{T}$ & NEO & CAS & DEL & $\operatorname{Am}(C \& N)$ \\
\hline 28. & Cucurbita pepo L. & Cucurbitaceae & ST & NEO & CAS & DEL & $\operatorname{Am}(\mathrm{C})$ \\
\hline 29. & Datura stramonium L. & Solanaceae & $\mathrm{T}$ & NEO & INV & ACC & $\operatorname{Am}(\mathrm{N})$ \\
\hline 30. & $\begin{array}{l}\text { Echinocystis lobata (Michx.) Torr. \& A. } \\
\text { Gray }\end{array}$ & Cucurbitaceae & ST & $\mathrm{NEO}$ & NAT & DEL & $\operatorname{Am}(\mathrm{N})$ \\
\hline 31. & Eragrostis minor Host & Poaceae & $\mathrm{T}$ & ARC & NAT & ACC & E AS \\
\hline 32. & Erigeron annuus (L.) Desf. & Compositae & $\mathrm{T} / \mathrm{H}$ & NEO & INV & $\mathrm{ACC}$ & $\operatorname{Am}(\mathrm{N})$ \\
\hline 33. & Erigeron canadensis L. & Compositae & $\mathrm{T}$ & NEO & INV & $\mathrm{ACC}$ & $\operatorname{Am}(\mathrm{N})$ \\
\hline 34. & Fagopyrum esculentum Moench & Polygonaceae & ST & ARC & CAS & DEL & As \\
\hline 35. & Galinsoga parviflora Cav. & Compositae & $\mathrm{T}$ & $\mathrm{NEO}$ & INV & ACC & $\operatorname{Am}(\mathrm{N})$ \\
\hline 36. & Galinsoga quadriradiata Ruiz \& Pav. & Compositae & $\mathrm{T}$ & NEO & NAT & $\mathrm{ACC}$ & $\operatorname{Am}(C \& N)$ \\
\hline 37. & Gleditsia triacanthos L. & Caesalpinieae & $\mathrm{P}$ & $\mathrm{NEO}$ & CAS & DEL & $\operatorname{Am}(\mathrm{N})$ \\
\hline 38. & Helianthus tuberosus L. & Compositae & G & NEO & INV & DEL & $\operatorname{Am}(\mathrm{N})$ \\
\hline 39. & Impatiens glanduliferaRoyle & Balsaminaceae & $\mathrm{T}$ & NEO & INV & DEL & As \\
\hline 40. & Ipomoea indica (Burm.) Merr. & Convolvulaceae & ST & NEO & CAS & DEL & $\operatorname{Am}(\mathrm{S})$ \\
\hline 41. & Ipomoea purpurea (L.) Roth & Convolvulaceae & ST & NEO & CAS & D-A & $\operatorname{Am}(\mathrm{C})$ \\
\hline 42. & Juglans regia $\mathrm{L}$. & Juglandaceae & $\mathrm{P}$ & $\mathrm{ARC}$ & CAS & DEL & As (SW) \\
\hline 43. & Juncus tenuisWilld. & Juncaceae & $\mathrm{H}$ & NEO & INV & $\mathrm{ACC}$ & $\operatorname{Am}(\mathrm{N})$ \\
\hline 44. & Lactuca sativa L. & Compositae & $\mathrm{T}$ & ARC & CAS & DEL & unknown \\
\hline 45. & Lepidium virginicum $\mathrm{L}$. & Brassicaceae & $\mathrm{T} / \mathrm{H}$ & NEO & INV & ACC & $\operatorname{Am}(\mathrm{N})$ \\
\hline 46. & Lycopersicon esculentum Mill. & Solanaceae & $\mathrm{T}$ & NEO & CAS & DEL & $\operatorname{Am}(S)$ \\
\hline 47. & Matricaria discoidea DC. & Compositae & $\mathrm{T}$ & NEO & INV & $\mathrm{ACC}$ & As (S\&E) \\
\hline
\end{tabular}




\begin{tabular}{|c|c|c|c|c|c|c|c|}
\hline & Taxon & Family & LF & PI & NAT & MI & $\mathrm{O}$ \\
\hline 48. & Medicago arabica (L.) Huds. & Fabaceae & $\mathrm{T}$ & ARC & NAT & ACC & $\mathrm{M}$ \\
\hline 49. & Medicago sativa $\mathrm{L}$. & Fabaceae & $\mathrm{H}$ & ARC & NAT & ACC & unknown \\
\hline 50. & Morus nigra L. & Moraceae & $\mathrm{P}$ & ARC & CAS & DEL & As (SW) \\
\hline 51. & Oenothera biennis L. & Onagraceae & $\mathrm{H}$ & NEO & INV & DEL & $\operatorname{Am}(\mathrm{N})$ \\
\hline 52. & Oxalis dillenii Jacq. & Oxalidaceae & $\mathrm{H}$ & NEO & NAT & ACC & $\operatorname{Am}(\mathrm{N})$ \\
\hline 53. & Panicum capillare L. & Poaceae & $\mathrm{T}$ & NEO & INV & ACC & $\operatorname{Am}(\mathrm{N})$ \\
\hline 54. & Papaver rhoeas L. & Papaveraceae & $\mathrm{T}$ & ARC & NAT & ACC & $\mathrm{M}$ \\
\hline 55. & Parthenocissus quinquefolia (L.) Planch. & Vitaceae & $S$ & NEO & INV & DEL & $\operatorname{Am}(\mathrm{N})$ \\
\hline 56. & $\begin{array}{l}\text { Parthenocissus tricuspidata (Siebold } \\
\text { \&Zucc.) Planch. }\end{array}$ & Vitaceae & $S$ & NEO & CAS & DEL & As (E) \\
\hline 57. & Persicaria maculosa Gray & Polygonaceae & $\mathrm{T}$ & ARC & NAT & DEL & As \\
\hline 58. & Persicaria orientalis (L.) Spach & Polygonaceae & $\mathrm{T}$ & NEO & CAS & DEL & As \\
\hline 59. & Phalaris canariensis L. & Poaceae & G & NEO & NAT & ACC & Af \\
\hline 60. & Portulaca oleracea L. & Portulacaceae & $\mathrm{T}$ & ARC & NAT & ACC & $\mathrm{M}$ \\
\hline 61. & Reynoutria japonicaHoutt. & Polygonaceae & G & NEO & INV & DEL & As (E) \\
\hline 62. & Robinia pseudoacacia L. & Fabaceae & $\mathrm{P}$ & NEO & INV & DEL & $\operatorname{Am}(\mathrm{N})$ \\
\hline 63. & Rudbeckia laciniata L. & Compositae & G & NEO & INV & DEL & $\operatorname{Am}(\mathrm{N})$ \\
\hline 64. & Sedum spurium M. Bieb. & Crassulaceae & $\mathrm{Ch}$ & NEO & CAS & D-A & As \\
\hline 65. & Sinapis arvensis L. & Brassicaceae & $\mathrm{T}$ & ARC & NAT & D-A & $\mathrm{M}$ \\
\hline 66. & Solanum tuberosum L. & Solanaceae & G & NEO & CAS & DEL & $\operatorname{Am}(\mathrm{S})$ \\
\hline 67. & Solidago gigantea Aiton & Compositae & $\mathrm{H}$ & NEO & INV & DEL & $\operatorname{Am}(\mathrm{N})$ \\
\hline 68. & Sorghum halepense (L.) Pers. & Poaceae & G & NEO & INV & ACC & $\mathrm{M}$ \\
\hline 69. & $\begin{array}{l}\text { Symphyotrichum novi-belgii (L.) G. L. } \\
\text { Nesom }\end{array}$ & Compositae & $\mathrm{H}$ & NEO & CAS & ACC & $\operatorname{Am}(\mathrm{N})$ \\
\hline 70. & $\begin{array}{l}\text { Symphyotrichum salignum (Willd.) G. } \\
\text { L. Nesom }\end{array}$ & Compositae & $\mathrm{H}$ & NEO & CAS & ACC & $\operatorname{Am}(\mathrm{N})$ \\
\hline 71. & Tagetes patula L. & Compositae & $\mathrm{T}$ & NEO & CAS & DEL & $\operatorname{Am}(S)$ \\
\hline 72. & Triticum aestivum L. subsp. aestivum & Poaceae & $\mathrm{T}$ & ARC & CAS & DEL & As (SW) \\
\hline 73. & Veronica persica Poir. & Plantaginaceae & $\mathrm{T}$ & NEO & INV & ACC & As $(W)$ \\
\hline 74. & Vicia sativa L. subsp. sativa & Fabaceae & $\mathrm{T}$ & ARC & NAT & ACC & $\mathrm{M}$ \\
\hline 75. & Vinca minor L. & Apocynaceae & $\mathrm{Ch}$ & ARC & CAS & DEL & $\mathrm{M}$ \\
\hline 76. & $\begin{array}{l}\text { Xanthium orientale L. subsp. italicum } \\
\text { (Moretti) Greuter }\end{array}$ & Compositae & $\mathrm{T}$ & NEO & INV & ACC & Am (N\&S) \\
\hline 77. & Zinnia elegans Jacq. & Compositae & $\mathrm{H}$ & NEO & CAS & DEL & $\operatorname{Am}(\mathrm{N})$ \\
\hline
\end{tabular}

